\title{
Da Filosofia à História: uma educação em movimento
}

uando saí do Seminário Arquidiocesano Maria Imaculada, localizado em Brodowski/SP, comecei a explorar o mundo laico que praticamente desconhecia. Era o ano de 1966. Eu havia permanecido na instituição por seis anos, sendo que o primeiro ano ginasial eu cursara no Seminário Diocesano Nossa Senhora da Paz de São José do Rio Preto - SP, minha cidade natal. Em 1967, os entreveros, se é que assim se pode dizer, para me adaptar à nova realidade, foram intensos. Passei a cursar o terceiro ano do curso então denominado Clássico no Instituto de Educação Monsenhor Gonçalves de São José do Rio Preto, fiz um curso de datilografia, não conhecíamos o computador, e, concomitante, frequentei um cursinho preparatório gratuito oferecido pela Faculdade de Filosofia, Ciências e Letras (FAFI), que viria a pertencer à UNESP como Instituto de Biociências, Letras e Ciências Sociais - IBILCE.

No terceiro ano do curso Clássico havia a disciplina Filosofia. A professora da disciplina era competente e apaixonada pelo filosofar. Conseguia despertar o nosso interesse e participação. Éramos poucos alunos, pois a maioria dos estudantes optava pelo Curso Científico e grande parte das meninas-moças frequentava o Curso Normal. As três modalidades de cursos, correspondentes hoje ao nível do ensino médio, preparavam para vestibulares em diferentes carreiras e o Curso Normal era profissionalizante. O Curso Clássico era mais voltado para a área de Ciências Humanas, de Ciências Jurídicas e Letras.

Nas aulas de Filosofia fizemos, dentre outras atividades, a apresentação de seminários individuais. Coube-me, não por acaso, mas por conta do meu passado recente, apresentar o pensamento de Tomás de Aquino. Investi na preparação da tarefa e acho que fiz uma boa

* Pesquisador do Grupo de Estudos e Pesquisas História, Sociedade e Educação no Brasil (HISTEDBR). E-mail: sanfelice00@yahoo.com.br 
comunicação, pois foi bastante elogiada pela rigorosa professora. Desde então passamos a fazer várias interlocuções, mesmo fora de aula. A professora, tomista, sempre me estimulava a optar por um vestibular em Filosofia, curso que eu teria compulsoriamente que fazer, caso tivesse permanecido no Seminário. Na formação eclesiástica os estudos filosóficos antecedem os teológicos.

Foi com muita incerteza sobre o próprio futuro que acabei tomando a decisão de ouvir minha professora. Não me arrependo até hoje, embora fosse estranho, mas também um tanto evidente, que dentre todos os colegas apenas eu tivesse optado pelo curso superior de Filosofia. E isso se constituiu num desafio imediato. A FAFI de São José do Rio Preto não oferecia o curso de Filosofia.

\section{A formação universitária}

O ano de 1968, de tantas referências para as pessoas da minha geração, foi o ano em que ingressei no Curso de Filosofia da PUCCAMP, após um exame vestibular cujo tema de redação foi “Ter ou Ser", simplesmente anotado no centro da lousa por um senhor que mais tarde viria a ser nosso professor: José Luiz Sigrist. Com o ingresso na PUCCAMP tive, então, que me mudar para Campinas.

Encontrei algumas surpresas. Todos os alunos homens do primeiro ano de Filosofia eram seminaristas, menos eu e um colega, já agora considerados ex-seminaristas. Havia também várias moças no curso e era destoante o fato de que a maioria dos alunos homens deveria estar prestando o serviço militar, mas não estava, porque eram seminaristas. Eu, como exseminarista, tive que prestar o serviço militar concomitante ao primeiro ano de Filosofia.

Em geral, os dois anos de Filosofia cursados na PUCCAMP propiciaram o ingresso no universo do pensamento filosófico. Caminhamos pela História da Filosofia Antiga e Medieval, detivemo-nos em problemas metafísicos, nos princípios da lógica formal, na teoria do conhecimento, em 
questões de cosmologia, antropologia e história da cultura. A história da filosofia antiga e medieval caminharam pelos manuais tomistas. Em outras disciplinas, não me lembro quais, lemos Sartre e Heidegger.

O curso, parece-me, abrigava basicamente três tendências: havia professores tomistas, fenomenólogos e existencialistas. Acontecia um embate de ideias, principalmente porque o existencialismo nos provocava sobremaneira e nos parecia historicamente muito oportuno. Fomos fazendo descobertas e entrando, cada vez mais, no clima daquela geração de 68 . Integrávamo-nos como era possível.

Um fato curioso é que dentre aqueles professores, o que mais nos encantava, aquele professor que nos parecia o mais filósofo de todos, aproximadamente vinte e cinco anos depois, foi identificado por mim, anonimamente perdido entre os demais alunos que cursavam uma disciplina que eu oferecia no Programa de Mestrado em Educação da UNICAMP. Fiquei entre a emoção e o constrangimento. O que a história teria reservado àquele homem que considerávamos brilhante? Infelizmente não houve grandes chances de reaproximação porque ele, agora meu aluno, veio a falecer antes de concluir o curso.

Como não dizer que, embora o curso de Filosofia atraísse de fato a maioria de nós, havia nos acontecimentos políticos do país e no movimento estudantil fortes solicitações para que nosso engajamento militante se ampliasse? Desde o início daquele ano de 1968 a movimentação estudantil universitária era grande e mais ainda após a morte do estudante Edson Luís Lima Souto, no Calabouço do Rio de Janeiro. Passei a participar ativamente do planejamento das passeatas e das manifestações. Aprendemos como o regime civil-militar se comportava nos anos pós-64 e, em Campinas, as tropas militares fortemente armadas ocupavam com frequência os locais públicos estratégicos. Tivemos que driblá-las ou, então, simplesmente correr delas.

Entre muitas assembleias, passeatas e a ocupação que fizemos do prédio central da PUCCAMP, alojando-nos nos porões do Pátio dos Leões 
por vários dias, chegavam-nos vagas notícias de que próximo a Campinas, praticamente numa fazenda, estava sendo montada uma universidade pública, ou seja, a UNICAMP. Para nós, seria mais uma universidade destinada aos ricos, dadas as características do ensino superior público da época: pouca oferta e, por consequência, elitizado.

O ano de 1968 foi repleto de fortes e muitos protestos pelo país inteiro. Chamou-nos vivamente a atenção o episódio da "Batalha da Rua Maria Antônia", em São Paulo, onde se confrontaram alunos da Filosofia da USP e alunos da Universidade Mackenzie. Não menos dramático, para nós estudantes, foi quando o XXX Congresso da União Nacional de Estudantes - UNE - caiu sob o aparato repressivo, com a consequente prisão de todos os seus participantes. A ditadura, nos seus anos pós-64, chegava cada vez mais perto de cada um de nós e vários estudantes do curso de Filosofia ou da PUCCAMP foram presos. Naquele ano, oficiais da Aeronáutica desejaram empregar a unidade de buscas e salvamentos da Força Aérea Brasileira FAB, em missões de assassinatos das lideranças estudantis, dos políticos da oposição e dos cassados considerados irrecuperáveis, episódio este que ficou conhecido como o caso Para-Sar.

A cada dia passado, nós sentíamos mais ódio da ditadura militar e de seus aliados internos e externos ao país. Nosso inconformismo com os rumos que iam sendo impingidos à sociedade acabava nos cegando quanto às nossas reais possibilidades de resistência, mesmo quando o autoritarismo tornou-se mais coercitivo com a edição do Ato Institucional número 5, ao final de 1968.

Dentre os muitos temas das discussões estudantis encontravam-se os chamados Acordos MEC-USAID e a Reforma Universitária que, de antiga bandeira do movimento estudantil, tornou-se o instrumento mais eficaz para a intervenção dos governos militares na universidade brasileira. $\mathrm{O}$ governo fez a reforma e buscou acomodar o ensino superior aos princípios do modelo econômico que representava. É possível dizer que parte dos estudantes era razoavelmente consciente da situação política, econômica e 
social que o país vivenciava, mas ainda assim houve muita manipulação por conta das inúmeras tendências que divergiam e orientavam as ações, nem sempre consequentes.

Quando iniciamos o ano de 1969, com o Ato Adicional número 5 já em vigor, o movimento estudantil acusava um refluxo e voltava novamente a ser atacado, juntamente com as Universidades, através do famoso DecretoLei número 477. Como o decreto definiu infrações disciplinares praticadas por professores, alunos, funcionários ou empregados de estabelecimento de ensino, espalhou-se entre nós um clima ainda maior de terror. A própria UNE não se refez do golpe sofrido no Congresso de Ibiúna e sucessivamente passaram a ocorrer novas prisões, banimentos e a clandestinidade como a única opção para muitos. Todos esses fatos teriam ainda desdobramentos futuros e condicionaram a formação daquela geração, ou pelo menos, de uma parte dela.

Com a intensidade com que se vivia, o nosso curso de Filosofia foi praticamente transformado, com a anuência e a participação da maioria de seus professores, em um lugar de reflexão política para respostas imediatas à situação. Lia-se, debatia-se, produzia-se textos sobre o que estava acontecendo. A PUCCAMP, por essas e outras razões internas, ingressou em profunda crise político-administrativa que culminaria com a demissão de numeroso grupo de professores. O corpo docente do curso de Filosofia foi integralmente atingido. Sucederam-se enfrentamentos, manifestações, greves, violência física, mas nada alterou a posição da Reitoria que contratou, pasmem os leitores, alguns padres jesuítas de São Paulo - Capital - e alguns leigos de confiança, para assumirem várias disciplinas cada um deles.

Nossa resistência esgotou-se quando ficou evidente que perderíamos o ano letivo, uma vez que nos recusávamos a assistir a aulas com os novos professores. Passamos então a permanecer nas salas sempre em silêncio sepulcral e absolutamente imóveis, para grande desconforto dos novos professores. Entre nós estudantes fizemos um acordo: assim que terminasse 
o ano letivo, todos os que pudessem abandonariam a PUCCAMP. O acordo foi cumprido! ${ }^{1}$

Tendo em vista o acordo estabelecido entre os alunos do curso de Filosofia da PUCCAMP, de abandonarem aquela instituição ao término do ano letivo, a instituição sofreu um esvaziamento significativo no final de 1969. Na medida das possibilidades pessoais e dos acertos burocráticos, nos transferimos, em grupos, para a PUC de Belo Horizonte, para a PUC do Rio de Janeiro e para a PUC de São Paulo. Houve também quem conseguisse sua matrícula na USP.

No meu caso, a solução foi me dirigir para a PUC de São Paulo, o que implicava novas descobertas e aprendizagens, agora na cidade de grande porte.

A PUCSP também tinha sua história reflexa daquele momento histórico, mas eu a desconhecia. O curso de Filosofia, com certeza, era bem

1Ao movimento estudantil da década de 60, eu retornei como pesquisador e dali construí o meu tema para a tese de doutoramento.

Os acontecimentos específicos da PUCCAMP, os revisitei com as pesquisas de alguns orientandos que visaram construir uma história daquela instituição. À instituição PUCCAMP retornei, também anos depois, como docente do seu curso de Filosofia.

Não posso olvidar-me de fatos que iriam marcar a história do Brasil e que têm sido objeto de documentários, romances, filmes ou trabalhos acadêmicos. Um deles, por exemplo, foi o sequestro do embaixador dos EUA no Brasil, Sr. Charles Elbrick, com o comando da operação exigindo a libertação de quinze presos políticos que, liberados e levados para fora do Brasil, passaram a ser considerados banidos. Em 1969, como já disse anteriormente, a clandestinidade e a luta armada pareciam ser as únicas alternativas. $\mathrm{O}$ medo, o terror mesmo, entretanto, aumentavam. O golpe militar decretou o Ato Adicional número 14, prevendo a pena de morte e a prisão perpétua em casos de "guerra revolucionária ou subversiva".

De modo contraditório ou sintomático, aqueles anos de ditadura acabaram sendo férteis para a música popular brasileira. Os festivais da TV Excelsior e da TV Record iam consagrando músicas que tomavam conta dos meios universitários: Arrastão de Vinícius de Moraes e Edu Lobo; A Banda de Chico Buarque de Holanda; Disparada de Theo de Barros e Geraldo Vandré; Máscara Negra de Zé-Keti e Hildebrando Pereira Matos; Ponteio de Edu Lobo; Domingo no Parque de Gilberto Gil; Roda Viva de Chico Buarque Alegria, Alegria de Caetano Veloso e Para não dizer que não falei das flores de Geraldo Vandré. As novas músicas cantadas por nós, na forma original ou com letras adaptadas para os nossos objetivos, "lavavam nossas almas" cheias de esperança. Éramos jovens e tínhamos o direito de sonhar. A música de Vandré, como se sabe, passou a se constituir em verdadeiro hino da nossa resistência. O movimento chamado Jovem Guarda, com o gênero iê-iê-iê, disputava seu espaço com o movimento Tropicalista lançado por Caetano e Gil.

Aos poucos fomos sendo alertados para o teatro, onde Plínio Marcos lançava Dois perdidos numa noite suja e Navalha na Carne. Quando a peça Hair passou a ser encenada, a frequência a ela tornou-se uma obrigação, assim como viria a ser uma obrigação a leitura do semanário Pasquim, jornal de humor sobre temas sérios. 
mais conservador do que o curso da PUCCAMP. O que havia ali de mais avançado era o pensamento social cristão representado na disciplina de Filosofia Social sob a responsabilidade do professor, político e futuro governador do Estado de São Paulo, Sr. Franco Montoro. Eram as únicas aulas com um certo vínculo aos problemas sociais sobre os quais realmente interessava refletir. Havia a vantagem, também, relacionada às informações que generosamente o professor dividia conosco sobre os acontecimentos políticos de bastidores e que não se tornavam de domínio público. As demais disciplinas eram ministradas por velhos padres tomistas, ou por leigos que divulgavam uma filosofia asséptica. Era uma filosofia por si mesma e os pensadores não eram contextualizados. Uma filosofia que talvez desejasse fazer jus ao rótulo de Filosofia Pura.

A maior parte das aulas da PUCSP era ditada ou, então, trabalhava-se com apostilas feitas pelo professor. Foram poucos os textos de autoria dos filósofos com os quais realmente tivemos contato. Outro exemplo do conservadorismo daquele curso é que a Filosofia, ou melhor, a História da Filosofia, concluiu-se no pensamento de Hegel.

O reacionarismo explícito, entretanto, era comandado a partir da disciplina Filosofia do Desenvolvimento. Por essa disciplina e pelo professor por ela responsável, chegavam até nós as verdadeiras recomendações de toda a lógica do projeto econômico, político e social defendido pela ditadura civil-militar. Inculcava-se a teoria do desenvolvimento com segurança e se arregimentavam, de forma ostensiva, estudantes que desejassem fazer cursos de aprofundamento organizados e administrados por instituições que recebiam recursos públicos ou das entidades empresariais. O professor da disciplina, Adolpho Crippa, dirigia o Convívio - Sociedade Brasileira de Cultura -, instituição que se notabilizou por aglutinar a intelligentsia da direita radical e empenhada em elaboração de ideologias.

Em 1970 e 1971, frequentando a PUCSP, não tive contatos diretos com o movimento estudantil, que passou a sobreviver fundamentalmente na 
clandestinidade. No nosso curso de Filosofia tinha-se a impressão de que nada acontecera antes e que nada estava acontecendo na política, exatamente nos momentos mais agudos da ditadura. Terminamos em paz o curso que nos fazia bacharéis e licenciados em Filosofia, muito distantes dos fatos que realmente estavam marcando, não os estudantes universitários, mas a classe operária do Brasil. Meu último gesto de rebelião foi recusar-me a comparecer a qualquer tipo de cerimônia pública referente à colação de grau. Não havia motivos para comemoração, mas ainda assim o diploma somente foi liberado pela PUCSP quando, privadamente, prestei o juramento na sala da Reitoria da Universidade ${ }^{2}$.

Do meu curso de Filosofia, realizado nas condições descritas, restaram muitas heranças, apesar do desconforto que haviam me causado insistentes posturas metafísicas. Nada, entretanto, diminuiu meu gosto pelo filosofar. O entendimento cada vez mais arraigado, desde uma percepção inicial, de que o pensamento filosófico necessita de condições de liberdade, acabou por ser em mim uma constante. Considero essencial a liberdade para se fazer perguntas, toda e qualquer pergunta, perguntas radicais e perguntas de qualquer natureza. Também considero essencial a liberdade de se ensaiar todas as respostas possíveis, mas principalmente aquelas que são consideradas vitais pelos homens ou pelas sociedades de uma época. Para mim, a postura filosófica exige a convivência com a pluralidade das visões de mundo, das visões de sociedade, das visões do que é o humano e das visões éticas das nossas relações. Sem a pluralidade, a Filosofia se transforma em religião. $\mathrm{Na}$ continuidade da minha formação eu descobriria que o conflito, que a contradição antagônica são inerentes a tudo o que é humano, mas antes de chegar lá, a Filosofia já havia exigido o pensar

2 É evidente que aquela paz interna da PUCSP não correspondia aos fatos externos porque desde 1970, por exemplo, ocorreram os sequestros do cônsul japonês em São Paulo, do embaixador da República Federal da Alemanha, no Rio, e do embaixador da Suíça, também no Rio. Os sequestrados iam sendo trocados por presos políticos, tornando pública a existência dos mesmos. Em 1971 foi morto o capitão Lamarca, provocando-nos uma sensação de que uma guerra oculta vinha acontecendo. No mundo cultural, mais uma vez o teatro nos atraía, com a encenação importante de $O$ Balcão de Jean Genet.

À PUCSP eu voltaria para cursar o mestrado, posteriormente o doutorado e ainda, também como docente. 
metódico, reflexivo, crítico e desestabilizador de certezas. Meu curso de Filosofia, nas suas ambiguidades e diferenças entre as orientações da PUCCAMP e da PUCSP, despertou-me para esses elementos, fez com que ensaiasse a prática deles e fosse incorporando-os ${ }^{3}$.

\section{O Curso de Mestrado}

Meu desejo de cursar o mestrado surgiu imediatamente após a conclusão da graduação em Filosofia. Circulavam na PUCSP notícias esparsas sobre um mestrado emergente em Filosofia da Educação e eu sentia que meu curso de graduação havia sido bastante tumultuado, e que era necessário impor-me uma formação mais sólida. A pós-graduação, por sua vez, era uma modalidade de ensino apenas emergente. Na PUCSP estavam sendo iniciadas as primeiras turmas de pós-graduandos.

A minha primeira tentativa de ingressar no mestrado, para minha alegria, foi bem sucedida. Algumas semanas depois, para minha inconformidade, fui avisado, por telefone, que ocorrera um equívoco e que não seria aceito no programa. Sempre por telefone, recebi várias explicações

3É preciso dizer que, quando na minha formação se impôs a ótica da história e mais especificamente da história da educação, todos estes fatos que até então pareciam pessoais, ganharam uma dimensão social muito ampla. Entender as profundas mudanças ocorridas no Brasil nas décadas de 50,60 e 70 ajudava, por exemplo, a compreender as características da minha família, uma dentre milhares nas mesmas condições; entender um pouco do papel da Igreja e da religião dentro de uma sociedade como a nossa, explicava boa parte dos fatos acima narrados e que também eram de natureza coletiva. Quando fui descobrindo o que havia sido o getulismo na política brasileira, o projeto nacional-desenvolvimentista e o populismo, o janismo, uma bandeira política da minha família, ampliaram-se as luzes sobre cada acontecimento que me parecia antes muito peculiar e específico. Romper com a visão anticomunista do pré-64, que havia nos arrancado tantas orações, foi um longo processo, mas compreensível à luz da história.

$\mathrm{Na}$ história da educação descobri porque o meu Grupo Escolar, cursado na década de 60, era tão elitizado, da mesma maneira que descobri porque o Instituto de Educação "Monsenhor Gonçalves", onde fiz o terceiro clássico, era, além de elitizado, tão conceituado na cidade. O mesmo ocorreu quando pude estudar o movimento estudantil e o modelo de ensino superior, no qual eu havia me formado.

Se a família tradicional, a Igreja e a religião católica, a escola e o serviço militar foram determinantes na formação de segmentos da minha geração, também o foram o movimento estudantil, a clandestinidade, a guerrilha urbana e rural, os partidos e as facções consideradas ilegais, bem como a convivência e a resistência de setores da sociedade civil à ditadura militar. A aprendizagem da tomada de consciência e da prática política, mesmo que não partidária, impuseram-se como necessidade histórica e aos solavancos. Desculpem-me a mesmice: que Pedagogia Social! 
pouco convincentes e tive que conviver com o estranho episódio por muitos anos. Fiz inúmeras conjecturas e nunca o entendi. Coisas da Academia!

No ano seguinte prestei novamente a seleção e, agora realmente aceito, passei a fazer um longo percurso que demoraria seis anos. Fiz o curso sem qualquer bolsa, vivendo limitações financeiras enormes e conciliando-o com muito trabalho. Não havia como correr e eu mesmo tive que vivenciar um processo de amadurecimento intelectual que acabou exigindo vários anos.

O mestrado da PUCSP, dentre outras coisas, funcionava como um espaço de refúgio. Os mestrandos socializavam suas experiências informalmente e trocavam suas informações sobre o quadro políticoeconômico do país. Havia muita identidade entre nós que vivíamos mais ou menos as mesmas condições históricas, profissionais e econômicas. Tornávamo-nos cúmplices de um diálogo existencial e sobre as perspectivas futuras de nossas vidas e da própria história do Brasil, marcadas pelas condições do regime militar. Caminhávamos com incertezas muito grandes.

Aquele mestrado tinha também a característica de um oásis. Parte de seus professores, com formação europeia recente, impunha ao programa uma tendência fenomenológica. Chegavam a ignorar as condições reais do Brasil que se estava vivendo, porque os seus últimos anos de vida tinham sido passados em terras europeias. Filosofavam com autores europeus, textos que não existiam em língua portuguesa e preferiam o francês para melhor expressarem suas ideias. Havia exceções.

Muitos mestrandos passaram a conturbar a paz daquele oásis, de um lado porque a PUCSP se fortalecia no plano político e intelectual de resistência à ditadura civil-militar e, de outro, porque precisávamos de reflexões mais voltadas para a realidade circundante. Era muita provocação ignorar o Brasil real que se vivia.

Por esses elementos, o oásis, em muitas ocasiões, converteu-se em campo de combate, pois aconteciam saudáveis conflitos de divergências e de efervescência intelectual que a situação provocava. Aos poucos 
aproximei-me de colegas que tinham laços com partidos de esquerda e clandestinos.

O curso de mestrado, penso hoje à distância, teve aspectos positivos fundamentais. Mesmo com a predominância da orientação fenomenológica, fazíamos muitas leituras paralelas e na maioria das vezes lendo os textos dos próprios autores e não mais somente os seus intérpretes ou manuais. Pouco ainda se estabelecia a relação entre Filosofia e Educação, mas o ambiente filosófico era dos mais provocativos e definia de vez para o meu futuro a convivência com a área. Para mim, e por conta dos estudos paralelos, começaram finalmente a se delinear algumas diferenças gritantes entre uma filosofia especulativa e uma filosofia da práxis, bem como as questões e a abrangência seja do pensamento lógico-formal, seja do pensamento lógicodialético. Era o início de um caminhar em direção ao pensamento marxista e que foi extremamente estimulado pela obra Filosofia da Práxis de A. S. Vázquez. Minha dissertação de mestrado, que comentarei posteriormente, talvez tenha sido fruto dessa etapa de passagem, mas que acabou tendo uma influência mais acentuada de autores cuja compreensão da realidade histórico-social não superava os limites de uma postura críticoreprodutivista.

Naquele mestrado, uma disciplina em especial exerceu grande atração sobre mim. A disciplina Filosofia da História propôs-se a fazer a abordagem do seguinte tema: Quem é o sujeito da história? A tentativa de responder a essa indagação levou-nos a percorrer textos de vários filósofos, da antiguidade à contemporaneidade, e com boa contextualização histórica. A temática me pareceu apaixonante, mas a forma como ela foi trabalhada fezme ver com muito mais clareza a necessidade imprescindível de não dissociar o pensamento filosófico da dimensão histórica e de, jamais, procurar compreender a história sem o aporte da Filosofia. A minha formação cada vez mais filosófica e a minha concomitante imersão profissional cada vez maior nas disciplinas históricas começaram a adquirir novo sentido. Acredito que essa descoberta foi decisiva porque ela passou a 
caracterizar, pelo menos como eu consigo ver, minha situação intelectual futura e até aos dias de hoje: estou sempre situado na relação entre a Filosofia e a História e, espero, atuando não em detrimento de ambas. Posteriormente viria a tentativa de fluir entre as relações da Filosofia com a História e dessas com a História da Educação, sem nunca pretender estabelecer limites de campo entre elas e sem nunca me preocupar ou marcar onde termina uma e onde começa a outra. Fazer essa demarcação seria sem sentido.

Finalmente, devo ainda à formação recebida no mestrado a definição de um objeto de pesquisa para todos os intentos futuros, ou seja, a educação. Tomada no sentido amplo, a educação converteu-se, independentemente do recorte que se faz em cada projeto de pesquisa ou em cada reflexão histórico-filosófica, teórico-prática, no eixo condutor de todas as minhas atuações acadêmicas. Por último, e não menos importante, foi também ali no mestrado que se colocou a necessidade efetiva de se voltar para a pesquisa e dar de fato os passos necessários para a sua execução. $\mathrm{Na}$ graduação não houve nunca essa preocupação ${ }^{4}$.

4 Por outro lado, é preciso lembrar que durante aqueles anos de mestrado, a repressão do regime militar havia desencadeado uma nova caçada aos militantes do Partido Comunista Brasileiro (PCB) e do Partido Comunista do Brasil (PC do B). O DOI-CODI de São Paulo continuava escrevendo sua história de assassinatos e torturas. Lá morreram o Tenente José Ferreira de Almeida, depois o jornalista Vladimir Herzog e o metalúrgico Manuel Fiel Filho. A ditadura já não conseguia controlar os filhos que gerara e em 1977, a pretexto de reprimir os estudantes que estavam tentando rearticular a UNE, a Polícia Militar comandada pelo Coronel Erasmo Dias invadiu a PUCSP sob os olhares apavorados de todos os estudantes, professores e funcionários. Lembro-me bem dos estragos materiais que foram provocados à instituição, dos ônibus que conduziam os estudantes presos e das universitárias que foram gravemente queimadas por bombas químicas. Fora do meio universitário, nas greves operárias, em confronto com a polícia viria a morrer o líder sindical católico Santo Dias da Silva em 1979. Mas antes disso, pelo ano de 1973, a polícia já havia assassinado o estudante paulista Alexandre Vannuchi Leme. Alimentando cada vez mais o terror, as sedes da Associação Brasileira de Imprensa (ABI), do Centro Brasileiro de Análises e Planejamento (CEBRAP), da Editora Civilização Brasileira e da Ordem dos Advogados do Brasil (OAB), sofreram atentados com cartas-bombas que provocaram mortes. As ações eram assumidas pela Aliança Anticomunista Brasileira (AAB). Muitos de nós se desesperavam porque a ditadura dava sinais de que poderia permanecer por todos os anos de nossas vidas.

Com o tempo, aquele quadro histórico complexo em que parte da minha geração foi sendo formada profissional e intelectualmente, com uma conscientização política aos solavancos, dada a contundência dos fatos, fomos descobrindo também alguns caminhos de esperança e sobrevivência. Comprávamos e líamos o jornal semanário Opinião e posteriormente o semanário Movimento, mesmo quando a maioria das suas páginas ficava 


\section{A dissertação de mestrado}

Concluí minha dissertação de mestrado em 1978, na PUCSP. O trabalho que apresentei recebeu o título Educação Brasileira Contemporânea - da necessidade de uma prática educacional discriminatória à impossibilidade de uma educação igual para todos.

Naquele texto da dissertação, na verdade minha iniciação no universo da pesquisa, eu ponderei que as preocupações primeiras que me haviam levado a produzi-lo estavam relacionadas a um possível estudo sobre o conceito de alienação. No percurso da investigação passei a considerar necessária uma postura menos metafísica e que se voltasse para explicitar uma situação de alienação em condições concretas.

Em busca da nova perspectiva acabei considerando que a educação formal é o meio institucionalizado pelo qual as sociedades contemporâneas viabilizam aos homens o acesso à parte da cultura disponível. Isto posto, passei a fazer um estudo da realidade educacional brasileira contemporânea, considerando em especial os dados disponíveis após 1964 e, na época, os dados mais recentes do recenseamento realizado em 1970. A ótica da pesquisa girou em torno do tema da democracia educacional, entendendo-se que a explicitação das oportunidades educacionais de uma população revela a sua participação no processo geral da distribuição da cultura em uma determinada sociedade.

A realização da pesquisa, em um primeiro momento, contou com o levantamento de dados que refletissem a realidade educacional brasileira e com a apresentação de aspectos da legislação. Foram arroladas informações sobre o ingresso escolar, a seletividade e assim por diante.

composta apenas de tarjas negras em decorrência da Censura. Era necessário que aquela imprensa não submissa ao regime militar resistisse com a nossa solidariedade.

Quer porque eram culturalmente gratificantes ou porque indicavam um vislumbre de futuro, muitos filmes e peças teatrais nos auxiliaram a viver aqueles dias. Podem ser lembrados: São Bernardo, baseado no romance de Graciliano Ramos, Toda nudez será castigada, A Estrela Sobe, Gota D’água, Dona Flor e seus dois maridos, Aleluia Gretchen, Lição de Amor, Tenda dos Milagres, Macunaíma e Ópera do Malandro, dentre outros.

Em 1979, mais uma pequena luz: a UNE tentou reiniciar sua reconstrução. Enfim, nem tudo havia sucumbido. 
Perante a contundência dos dados, expressivos na demonstração de uma ausência de democracia educacional no país, apesar das proclamações legais, enveredei pelas hipóteses explicativas de que aquela constatação mostrava a condição mesma de funcionamento da escola, cumprindo adequadamente seu papel, e, mais do que isso, impossível de se constituir em uma escola democrática por estar inserida em uma sociedade de classes.

Em favor da minha hipótese apresentei novos dados de ordem econômica e das profundas diferenças entre as classes sociais da realidade social brasileira, para concluir que estes determinantes eram os que, de fato, condicionavam as oportunidades dos indivíduos e classes em relação à escolaridade, mas não só em relação a ela.

$\mathrm{Na}$ sequência, coloquei-me a fazer considerações teóricas e históricas sobre o papel da educação e, em especial, da escola nas sociedades de classes. Embora eu contasse com o apoio bibliográfico de obras como Alienação e Humanismo (Leôncio Basbaum), A Origem da Família, da Propriedade e do Estado (F. Engels), Lógica Formal, Lógica Dialética (H. Lefébvre), Manuscritos Econômicos e Filosóficos (Karl Marx), Ciência e Existência (Álvaro V. Pinto), Educação e Luta de Classes (Aníbal Ponce) e Filosofia da Práxis (A. Sanchez Vázquez), minha concepção a respeito do papel da educação na sociedade de classes limitou-se a uma visão reprodutivista e, muito provavelmente, sob a influência da obra Escola, Estado e Sociedade (Bárbara Freitag) e alguns outros textos recentes na ocasião, mas sem ter o conhecimento teórico da contribuição críticoreprodutivista ou dos seus principais autores. O título da dissertação, já anunciado, é o exemplo claro dos limites daquele trabalho, embora como crítica ele tivesse também sua contundência.

Finalmente, para resgatar o ponto de partida daquela investigação, voltei-me à questão da alienação, considerando-a concretamente na situação em que os discriminados pela escola não têm também o acesso à cultura socialmente disponível. Na sequência, fiz uma série de tentativas no sentido de tentar sair do impasse, de lançar alguma perspectiva possível para os 
professores que pretendessem ter um compromisso com uma educação democrática e aí incorporei influências de textos de Paulo Freire, textos talvez esperançosos, mas, sem querer ser injusto com a importância histórica do ilustre educador, textos pouco dialéticos. A minha tentativa de sair da armadilha reprodutivista acabou sendo mais de esperança e voluntarismo, para uma possível resistência ao que estava historicamente estabelecido. De forma positiva, entretanto, eu sugeria um trabalho coletivo e que implicaria conquistas, uma vez que a educação democrática não viria por parte das iniciativas do Estado. Também me parece que foi positivo não tomar a educação fora dos seus condicionantes do contexto histórico-social.

Ficou, de forma inesquecível, marcada a posição de um dos examinadores da dissertação, na defesa pública, que insistiu contundentemente em que eu deveria dar uma alternativa concreta para a realidade educacional que eu havia denunciado e criticado tanto. Não dei. Eu ainda não conhecera obras de G. Snyders que seriam no futuro decisivas na minha própria formação. O meu orientador no mestrado foi o professor Moacir Gadotti.

\section{O curso de doutorado}

Cursar o doutorado em Educação passou a ser para mim um imperativo, tendo em vista os rumos profissionais que vinham se delineando, meus propósitos futuros e também a necessidade objetiva de continuar o processo da própria formação. Como no mestrado, o percurso mais uma vez foi lento: cinco anos se passaram. Cinco anos ricos em um processo de amadurecimento intelectual e de convivência com colegas muito instigantes.

Posso considerar que, como as minhas condições de trabalho iam ficando mais favoráveis, além das próprias condições vividas politicamente no Brasil, foi um privilégio fazer o doutoramento também na PUCSP. O grupo de doutorandos daquelas turmas viria a constituir, na sua maioria, uma referência nacional na educação brasileira, bem como no que diz respeito à produção da área. 
O doutorado foi um lugar onde a seriedade, o estudo, a pesquisa e os debates constituíram-se no cerne de todo o programa. Houve muita responsabilidade por parte dos docentes e dos doutorandos, no desenvolvimento das atividades realizadas de forma marcadamente coletiva. A maioria das teses concluídas teve inclusive um caráter de complementaridade orgânica entre elas, de modo que a participação do conjunto de doutorandos no trabalho de cada um foi decisiva.

As disciplinas de Filosofia da Educação I e II, bem como Teoria do Conhecimento, propuseram leituras sistemáticas dos autores conhecidos pelas suas características reprodutivistas na forma de entenderem a sociedade e a educação, leituras rigorosas de obras de Engels e Marx e, com muita pertinência, leituras das obras de Antonio Gramsci. Pudemos pensar o fenômeno educativo sob o prisma que o considera resultante de múltiplas determinações, mas não determinista. Aos poucos foi possível ir superando os vieses reprodutivistas e burilando, com mais rigor, a compreensão dialética da história, das sociedades e da educação. Em paralelo eu vivia a intensa discussão política e teórica que ocorria no âmbito de partidos políticos.

Reconheço que desde aqueles anos até hoje, venho tentando manterme coerente, do ponto de vista histórico-filosófico e epistemológico, com os princípios gerais do materialismo dialético. É esta a orientação que procurei dar às disciplinas que fui ministrando, às propostas de pesquisa e aos escritos que produzi e divulguei. É um esforço, mas eu mesmo não sou o melhor crivo para indicar se ele tem garantido a coerência desejada.

Por outro lado, essa busca de coerência, penso, não foi um tapa-olhos que me fizesse aderir a dogmas, que me tornasse surdo às vozes de diálogo com outras posições teóricas, ou que me afastasse da defesa do pluralismo teórico ideológico, quer na Academia, quer na Política. Evito, entretanto, fazer concessões ao ecletismo ou a comportamentos pretensamente não posicionados. Da minha parte, procuro sempre estar definido, mesmo que essa definição possa ter um caráter provisório. 
O curso de doutorado foi, portanto, para mim, a oportunidade de uma definição-adesão, bastante consciente, aos instrumentos teóricos e metodológicos que considerei os mais abrangentes para a compreensão da história, da realidade social, da educação e inclusive para as ações políticas.

Hoje, venho acompanhando tanto quanto me é possível as situações históricas que estão se delineando e o reflexo que imprimem ao debate teórico. Não estou em crise quanto aos fundamentos teóricos com os quais trabalho e penso que o materialismo histórico-dialético é ainda suficientemente amplo para responder a boa parte das atuais mudanças globais. Não é a única possibilidade, mas talvez seja a de maior alcance e profundidade. É uma questão em debate e gosto dela.

\section{A Tese de Doutorado}

O doutoramento, cursado na PUCSP, foi concluído no ano de 1985, com a apresentação da tese intitulada Movimento Estudantil - a UNE na resistência ao golpe de 64.

Esse trabalho, de caráter historiográfico, teve por objetivo investigar o envolvimento da União Nacional dos Estudantes nas principais questões educacionais e da vida nacional que se apresentaram no Brasil ao longo da década de 60. O que se quis analisar foi o papel desempenhado pela UNE como entidade que, falando pelos estudantes, como tal foi tratada pelo poder pré e pós-64, bem como por aqueles que buscaram lhe fazer oposição no sentido de sua desarticulação. Tomou-se a evidência de que, no período em questão, a UNE foi um palco de exercício político das tendências consideradas naquelas circunstâncias ideologicamente de esquerda, combatidas pelas ideologias denominadas de direita.

Para alcançar o objetivo almejado, dei prioridade à recuperação das expressivas análises, das propostas, das posições e orientações da UNE na década de 60, relacionadas aos interesses específicos do movimento estudantil e também à vida política no Brasil. No transcorrer do trabalho abri espaços para que aparecesse o discurso e o pensamento da UNE, 
permeando-os com o registro dos acontecimentos com os quais se relacionavam, de modo que se pudesse fazer transparecer a sua lógica. Foi uma tentativa de examinar a produção teórica da UNE naquela década. Evidentemente, tive o cuidado de registrar também que entendia ser, o material utilizado, representativo das tendências hegemônicas no movimento estudantil e não o reflexo puro e simples dos níveis de politização ou atuação de cada entidade estudantil ou de cada estudante.

Outro cuidado constante naquele trabalho foi em relação a uma aproximação, a melhor possível, da identificação dos estudantes universitários e suas respectivas origens sociais, bem como sua representatividade no contexto da sociedade brasileira, evitando tomar a parte pelo todo. Da mesma maneira evitou-se considerar os estudantes como uma classe social, para não tomá-los como um dos principais polos do conflito entre as classes sociais, mas não desconhecendo a relevância conjuntural que o movimento estudantil adquiriu no conflito das classes. O mais significativo, todavia, era explicitar, para além do confronto entre o movimento estudantil e os governos militares, o antagonismo central entre a burguesia e o proletariado.

À produção teórica da UNE, como contraponto, apresentaram-se os discursos, as orientações e as ações produzidas e apregoadas pelos governantes do movimento de 64. Tratava-se de perceber, tanto quanto possível, o real significado do embate dos estudantes com os primeiros governos militares.

Em um esforço de interpretação do que havia viabilizado o movimento de 64, alicercei-me primeiro nos documentos oficiais da UNE, tais como: Declaração da Bahia: Primeiro Seminário Nacional de Reforma Universitária, Declaração de Porto Alegre, Resoluções do Conselho da UNE: encontro sobre Reforma Universitária, Declaração de Princípios do XXVIII Congresso, Plano de Ação para o exercício 1966-1967, Carta Política da UNE, dentre muitos outros. Utilizei-me também de uma bibliografia sociológica ou histórica sobre estudantes universitários e 
tendências do movimento estudantil, para me transpor a um nível de análise com o auxílio de uma literatura da qual destaco: Beabá do MEC-USAID (Márcio Moreira Alves), Estado e oposição no Brasil: 1964-1984 (Maria H. Moreira Alves), Reforma Universitária e Mudança Social (F. Fernandes), O estudante e a transformação da sociedade brasileira (Maralice M. Foracchi), A burguesia brasileira (J. Gorender), O colapso do populismo no Brasil (O. Ianni), A ditadura do grande capital (O. Ianni), O Estado na sociedade capitalista (Ralph Miliband) e mais uma razoável bibliografia emergente sobre a ditadura militar e as implicações relacionadas à educação.

Foram muitos os arranjos documentais que fiz para garantir a voz da UNE, a voz dos governos militares sobre o movimento estudantil e as reformas sociais da educação, bem como os esforços para compreender criticamente o que de mais radical havia acontecido na história recente da sociedade brasileira.

Os estudantes não eram, com certeza, o principal alvo da ditadura civil-militar e das forças econômicas e sociais que a haviam conduzido ao poder. Tratava-se, portanto, de aclarar essa questão, mas sem perder a especificidade da tese.

Na ocasião da defesa pública, um examinador da mesma lamentou-se por eu não ter feito um debate com alguns escritos seus sobre a UNE. Um outro criticou-me pela ausência de julgamentos sobre o Movimento Estudantil, aspectos que eu realmente não desejara incorporar no trabalho. Eu queria garantir a história de um período da UNE, com o mais vasto conjunto de informações e documentos que me fosse possível apresentar. Minha pretensão teórica, após todas as leituras e estudos do curso de doutorado, era a de ter superado a visão meramente reprodutivista da sociedade capitalista, a visão conspiratória da história e estabelecido uma análise dialética de uma conjuntura do desenvolvimento capitalista no Brasil $^{5}$. O meu orientador no doutorado foi o professor Evaldo Vieira.

5 No ano de 1986 tornou-se possível a publicação integral do texto da tese que, com cortes, revisões e adaptações, transformou-se em livro com o título original do trabalho, publicado pela Cortez Editora \& Autores Associados. Após as primeiras divulgações do livro, um professor do programa de doutorado da PUCSP publicou uma crítica no jornal Folha de 


\section{A Docência}

Iniciei-me como docente já em 1969, quando ainda cursava o segundo ano

de Filosofia na PUCCAMP. Nunca mais parei, até hoje. Durante praticamente uma década ${ }^{6}$ me "especializei" em aulas para a então modalidade denominada Curso de Madureza, depois Supletivo. Andei também pelos cursinhos preparatórios aos vestibulares. Fui desvendando a capital paulista pelas minhas andanças por esse tipo de escolas ${ }^{7}$. Fui "inventando" também o meu jeito de ser professor. Quase sempre ministrei disciplinas de História Geral e de História do Brasil. No campo da História tive de ser autodidata. Fui aos poucos caminhando dos manuais aos clássicos. Penso que construí uma visão relativamente ampla do conhecimento histórico e que muito veio a me auxiliar quando passei a trabalhar com as disciplinas filosóficas. Em geral as disciplinas filosóficas foram ministradas em cursos de nível superior. Passei por cursos de História, de Filosofia, de Serviço Social, de

São Paulo, dizendo que faltava àquela obra ter estabelecido as relações entre o Movimento Estudantil da UNE e o clima da rebelião juvenil europeia. De fato, eu não havia chegado a tanto, mas desconheço, até então, que houvesse algo denso e extenso escrito sobre a UNE.

Uma das consequências desse trabalho é que passei a fazer muitas palestras a estudantes universitários empenhados no movimento estudantil dos anos posteriores e, até os dias de hoje, sou convidado a participar de bancas que tratam do mesmo tema

6 A década de 80 , como se pôde saber gradativamente ao longo dela, ou como muito se veio a saber depois, foi o ápice da ditadura civil-militar que representava o Movimento de 1964. O chamado "milagre econômico brasileiro", a conquista do tricampeonato mundial pela seleção nacional de futebol, o ufanismo oficial e ideológico escondiam o que de fato acontecia no país, quer no que dizia respeito ao aumento da exploração da classe trabalhadora, quer em relação à repressão que se instaurara sobre ela e outros segmentos da sociedade.

7 Em duas situações durante esse período, tive a certeza de que a ditadura militar continuava muito atuante na repressão. A primeira delas foi quando ao atravessar a Praça da República no centro de São Paulo, uma certa noite, vi jogado sob um banco um rapaz que imediatamente reconheci: era um amigo dos tempos do movimento estudantil em Campinas. Ele ali estava havia horas, após ter sido solto pelos órgãos de segurança. Aturdido, desorientado, esfomeado, ele não tinha a menor ideia do que fazer. Apesar do receio de uma possível armadilha, levei-o para a pensão onde eu morava. Ali ele ficou refazendo-se de traumas e tentando reconstruir a vida. Moramos juntos vários anos e ele acabou tempos depois tornando-se importante referência no movimento que desencadeou a luta pela volta do ensino de Filosofia no segundo grau. Este amigo, infelizmente veio a falecer precocemente.

Em outra situação fui procurado por líderes estudantis da USP, também antigos amigos do movimento estudantil em Campinas, para que ajudasse a esconder o presidente da UNE na clandestinidade. A pensão em que eu morava foi considerada segura para o propósito desejado. Para lá ele se foi e ali permaneceu alguns meses. Novamente quando por questões de segurança teve que abandonar a pensão, logo foi assassinado. Seu nome consta ainda hoje na lista dos desaparecidos do regime militar. 
Comunicação, de Enfermagem em várias instituições do $\mathrm{ABC}$ paulista, da Baixada Santista, do Vale da Paraíba, da UNESP-Marília, do Centro Pedagógico de Dourados - atualmente Centro Universitário da $\mathrm{UFMS}^{8}$-, da capital e de Campinas ${ }^{9}$. Enfim, foi um verdadeiro périplo até me tornar docente-pesquisador, em Regime de Dedicação Exclusiva, da UNICAMP.

No périplo, e por conta das necessidades impostas pelas disciplinas para as quais eu era contratado, praticamente fiz um novo curso de Filosofia. Acredito que até de melhor qualidade do que a minha graduação. Como eu sempre optei por trabalhar com textos dos próprios autoresfilósofos, enveredei seriamente pelas suas obras: de Platão a Hegel, de Agostinho e Aquino a Marx e Gramsci, pelo pensamento utópico, pela filosofia política, pela teoria do conhecimento e muitas outras caminhadas. Os manuais e os intérpretes auxiliavam, mas não eram os principais. A junção da história com a filosofia tornou tudo mais consistente e saboroso. Talvez seja essa a causa que fez aumentar meu apreço pela filosofia materialista-histórica e dialética, com a qual busquei cada vez mais ser coerente $^{10}$.

8Nos quatro anos de trabalho no CPD senti bem de perto um dos braços da ditadura. Em 1977 foi criada uma comissão de sindicância presidida, nada mais, nada menos, por um coronel travestido de pró-reitor. Surgiu daí um Processo Administrativo com audiências em horários e locais estapafúrdios, intimidadoras e sem que os professores acusados tivessem acesso aos autos. Vários colegas e eu fomos demitidos "por justa causa". Motivos? Defesa do anarquismo, oposição pública ao regime político vigente, estímulo à agitação estudantil etc., etc., etc... Eu ainda não havia aprendido que na instituição Universidade também se encontram arraigadas as forças reacionárias, conservadoras e arbitrárias.

9 Em duas instituições tive problemas explícitos de censura e perda do emprego. Em uma delas o pivô do desentendimento foi o uso do livro Ética de A. S. Vázquez. Em outra, foi decorrente da adoção do livro $O$ que é Filosofia do Caio Prado Júnior. Em uma terceira instituição fui alertado de que não seria suportável usar textos de Paulo Freire.

10 Concomitantemente houve avanços da sociedade civil na resistência à ditadura militar. Atravessaram-se os anos 70 sob a égide da Segurança Nacional, que, antes concebida na ótica da agressão externa, havia se convertido a uma lógica da Doutrina de Segurança Interna, sob o argumento da guerra psicológica e da necessidade de combater, destruir o inimigo interno. Apesar disso, de várias maneiras a oposição à ditadura militar foi se configurando, quer em processos eleitorais, quer em manifestações das camadas médias da população ou de setores da elite, bem como pela atuação da OAB, da ABI, da CNBB e mesmo pelo uso que se passou a fazer do partido MDB, como veículo dos anseios da oposição.

É bem verdade que houve momentos de recrudescimento da repressão, da censura, das torturas e mortes nas prisões, mas ampliava-se a pressão para que o Estado se liberalizasse. Começavam a surgir novas perspectivas quando se presenciavam, por exemplo, o Movimento contra o Custo de Vida e a emergência de um movimento popular das Comunidades Eclesiais de Base ligadas à Igreja Católica, dos grupos associativos 
Nos anos vividos na UNICAMP continuei conhecendo e aprendendo muito do pensamento filosófico e das "filosofias". Tive ilustres colegas de departamento, seguidores das mais variadas tendências, provocativos, desafiadores, mas respeitosos e democráticos. Nos cursos ministrados coletivamente, vários docentes em uma mesma disciplina, tivemos os melhores momentos de reflexão. E, sem pessimismo, resta concluir: ainda falta tanto...

seculares e o novo movimento sindical com as grandes greves do período 1978-1980. Em especial foram alentadoras, já em 1979, as Leis da Anistia e da Reforma Partidária. A primeira ainda de caráter muito restrito e a segunda, uma estratégia articulada para evitar o crescimento do partido de oposição, mas ambas manifestações explícitas de que a ditadura estava esgotando suas artimanhas de reciclagem. Tanto quanto possível eu participava das manifestações públicas que iam se ampliando, principalmente aquelas que ocorriam na Catedral da Sé ou na Praça da Sé, na capital paulista, mas ainda sob grande aparato repressivo. Continuavam os enfrentamentos de rua. No período tive muito contato com uma literatura clandestina que circulava entre alunos e professores. 